Original Research Paper

\title{
The Evaluation of Proton Pump Inhibitor Bioactive Fraction DLBS2411 from Cinnamomum burmannii (Nees \& T. Nees) in Animal Model of Gastric Ulceration Healing
}

\author{
Florensia Nailufar and Raymond Rubianto Tjandrawinata \\ Dexa Laboratories of Biomolecular Sciences, Industri Selatan V Block PP no.7, \\ Jababeka Industrial Estate II, Cikarang, West Java 17550, Indonesia
}

Corresponding Author:
Raymond Rubianto
Tjandrawinata
Dexa Laboratories of
Biomolecular Sciences, Industri
Selatan V Block PP no.7,
Jababeka Industrial Estate II,
Cikarang, West Java 17550,
Indonesia
Ph:+62-21-89841901
Fax:+62-21-89841905
Email: raymond@dexa-medica.com

\begin{abstract}
DLBS2411 is a bioactive fraction from Cinnamomum burmannii that is believed to possess anti-ulceration activity. In this study acetic acid was administered to induce gastric ulcer. Rats were divided into six groups: Healthy animals, untreated animals (acetic acid-induced), treatment group of BAF DLBS2411 $25 \mathrm{mg} \mathrm{kg}^{-1}$ Body Weight (BW), BAF DLBS2411 50 $\mathrm{mg} \mathrm{kg}{ }^{-1} \mathrm{BW}$ and positive control group of omeprazole $2 \mathrm{mg} \mathrm{kg}^{-1}$ and sucralfate $100 \mathrm{mg} \mathrm{kg}^{-1} \mathrm{BW}$. The efficacy of DLBS2411 was measured through histopathology examination and ulceration observation. Hematological parameters were also evaluated before and after treatments to indicate the safety profile of DLBS2411. The untreated animals developed more serious injuries (i.e., bigger and more severe ulcers) than the positive control groups and DLBS2411 treatment groups. DLBS2411 treatment with doses of 25 and $50 \mathrm{mg} \mathrm{kg}^{-1}$ and sucralfate $100 \mathrm{mg} \mathrm{kg}^{-1}$ were effective to heal the ulcer as shown by reduction of ulcer size (up to $54.8,36.53$ and $14.85 \%$, respectively) compared to the untreated animals. DLBS2411 was as effective as omeprazole $2 \mathrm{mg} \mathrm{kg}^{-1}$ and sucralfate 100 $\mathrm{mg} \mathrm{kg}{ }^{-1}$ in alleviating ulcer severity as examined in histopathology result. There were no significant differences in hematological values. DLBS2411 at doses of 25 and $50 \mathrm{mg} \mathrm{kg}^{-1}$ demonstrated healing activity on acetic acid-induced gastric ulcer, with a similar effect to that of omeprazole at dose of $2 \mathrm{mg} \mathrm{kg}^{-1}$ or sucralfate at dose of $100 \mathrm{mg} \mathrm{kg}$. No adverse reaction was seen in all treatment groups, suggesting that DLBS2411 has a good safety profile in animal.
\end{abstract}

Keywords: DLBS2411, Cinnamomum burmannii, Gaster, Ulceration, Rats

\section{Introduction}

Peptic ulcers are injuries in the mucosal areas immersed in gastric acid and pepsin, wherein normally the areas is covered with mucin secreted from mucus cells. Ulceration results from imbalance between gastroprotective activity and aggressive factors such as acidpepsin secretion, mucosal barrier, mucus secretion, blood flow, cellular regeneration, prostaglandins and epidermal growth factors (Bae et al., 2011; De Barros et al., 2008). It is one of the most common gastrointestinal disorders in clinical practice which is generally treated with modern medicines such as sucralfate and omeprazole. Considering potential side effects arising from these medicines, such as constipation, decreased bone mineral density and hematopoietic events sue to higher aluminium concentration, novel medicines should be sought for as an alternative in treatment of internal diseases (Dallwig, 2010; Papich, 2016; Odeh and Oliven, 2001; Yanagihara et al., 2015).

In recent years, we have conducted many studies on the potential use of herbal extracts for treatment of different kinds of diseases, especially on Cinnamomum burmannii extract for diabetes treatment. Combined with Lagerstroemia speciosa, C. burmannii has been found to induce insulin sensitivity in vitro as well as in patients in clinical studies (Nailufar and Tjandrawinata, 2011; Sitepu et al., 2016; Manaf et al., 2016; Kartolo et al., 2016; Tjandrawinata et al., 2013; Tandrasasmita et al., 2011; Tandrasasmita et al., 2014; Tjandrawinata et al., 2011). 
DLBS2411, a bioactive fraction containing $C$. burmannii, has previously been proven to affect hydrogen potassium adenosine triphosphate $\left(\mathrm{H}^{+} / \mathrm{K}^{+}\right.$ ATPase) activity as well as to down-regulate the gene expression. DLBS2411 was also reported to possess antioxidative activity (Tjandrawinata et al., 2013). Such pharmacological property would be beneficial for treatment and prevention of peptic ulcer. This paper further delved into the potential of DLBS2411 as an ulcer healing agent fractionated from C. burmannii. In this regard, DLBS2411 was studied in rat model of gastric ulceration.

\section{Material and Methods}

\section{Materials}

Cinnamomum burmannii was purchased from local suppliers (West Sumatera, Indonesia). This plant has been identified by the Herbarium Bogoriense, Research Center of Biology, Indonesian Institute of Sciences with certificate 1261/IPH. 1.02/If.8/XII/2009. Acetic acid (analytical grade) was obtained from Merck. Sucralfate powder (batch No. 400083635) was obtained from Dexa Medica, Palembang, Indonesia. Xanthan Gum (batch no. 100192618) was supplied by Ferron Par Pharmaceutical, West Java, Indonesia. Semi-automated hematology analyzer MEK-6450K and cell packs diluents were obtained Nihon Kohden, Japan.

\section{Preparation of DLBS2411}

The dried $C$. burmannii bark was milled and macerated in water for $2 \mathrm{~h}$ and concentrated to approximately $1 / 10$ of its initial volume and fractionated with methylene chloride to allow the aqueous phase to separate from the organic phase. The aqueous phase was then concentrated to eliminate any residual methylene chloride. The resulting concentrate was dried in an oven and the dried product was milled using Cone Mill (Comil underdrium 197, Quadro, Canada) and stored in a well-sealed container.

\section{Animals}

Thirty five young adult male Wistar rats (Rattus norvegicus) weighing around 250-300 grams were used in this study and housed individually in polysulfone cage and maintained under standard conditions (12 h light-12 $\mathrm{h}$ dark cycle, $25 \pm 2{ }^{\circ} \mathrm{C} ; 30-70 \%$ humidity).

All procedures in this experiment has been reviewed and approved by the Institutional Animal Care and Use Committee (IACUC), Dexa Laboratories of Biomolecular Sciences (DLBS), with protocol number DIS-DLBS-PROC-006 and carried out in accordance with the Association for Assessment and Accreditation Laboratory Animal Care (AAALAC) International.

\section{Experimental Procedures}

The experiment was carried out according to the method by Okabe et al. (1971) with minor modifications.

\section{Pilot Study (Ulcer Producing Study)}

Twelve hours prior to blood sampling and surgery, rats were fasted and placed in metabolic cages (no food, water ad libitum), in order to avoid any interferences of gastric acidity degree that could cause disturbance in ulcer induction. After fasting, blood was collected and surgery was performed to induce ulcer (Day-0). Three days after surgery, five rats were euthanized with pentobarbital injection.

\section{Full Study}

Animals were divided into six groups, which are healthy animals $(\mathrm{n}=5)$, untreated animals $(\mathrm{n}=5)$, treatment group I (DLBS2411 dose of $25 \mathrm{mg} \mathrm{kg}^{-1}$ Body Weight $(\mathrm{BW})$, orally, $\mathrm{n}=5$ ) and treatment group II (DLBS2411 dose of $50 \mathrm{mg} \mathrm{kg}{ }^{-1} \mathrm{BW}$, orally, $\mathrm{n}=5$ ), positive control group I (omeprazole $2 \mathrm{mg} \mathrm{kg}^{-1} \mathrm{BW}$, orally, equivalent to $22.4 \mathrm{mg}$ in human, $\mathrm{n}=5$ ) and positive control group II (sucralfate $100 \mathrm{mg} \mathrm{kg}^{-1} \mathrm{BW}$, orally, equivalent to $1.12 \mathrm{~g}$ in human, $\mathrm{n}=5$ ).

Twelve hours before blood sampling and surgery, rats were fasted and placed in the metabolic cage (no food, water ad libitum). After fasting, blood samples were collected and surgery was performed to induce ulceration with acetic acid. Three days after surgery (day 1 of treatment), the animals were treated with placebo (for healthy animals and untreated animals), DLBS2411 at dose of 25 and $50 \mathrm{mg} \mathrm{kg}^{-1} \mathrm{BW}$ (for treatment groups), omeprazole $2 \mathrm{mg} \mathrm{kg}^{-1} \mathrm{BW}$ and sucralfate $100 \mathrm{mg} \mathrm{kg}^{-1} \mathrm{BW}$ (for positive control groups) for seven days. At the end of the experiment, rats were euthanized using pentobarbital injection. Pathology condition of gaster, ulcer area and hematological data were observed in this study.

The schematic description of the experimental treatment is provided in Fig. 1.

\section{Operating Procedure}

After $12 \mathrm{~h}$ of fasting, rats were anesthetized with ketamine mixed with xylazine at dose of 40-80 and 5-10 $\mathrm{mg} \mathrm{kg}{ }^{-1} \mathrm{BW}$, respectively, via intra-peritoneal route. Acetic acid solution $(80 \% \mathrm{v} / \mathrm{v}, 500 \mu \mathrm{L})$ was placed on serosal surface of the gaster in its corpus region and allowed to remain in contact for $30 \mathrm{sec}$. The area that were in contact with acid were rinsed gently with saline and the abdomen were closed with suture. For healthy animals, acetic acid solution was replaced with aquadest for injection. Neomycin powder was applied at the site of operation in order to avoid post surgical infection. Day 3 post surgery was considered as day 1 of treatment. 


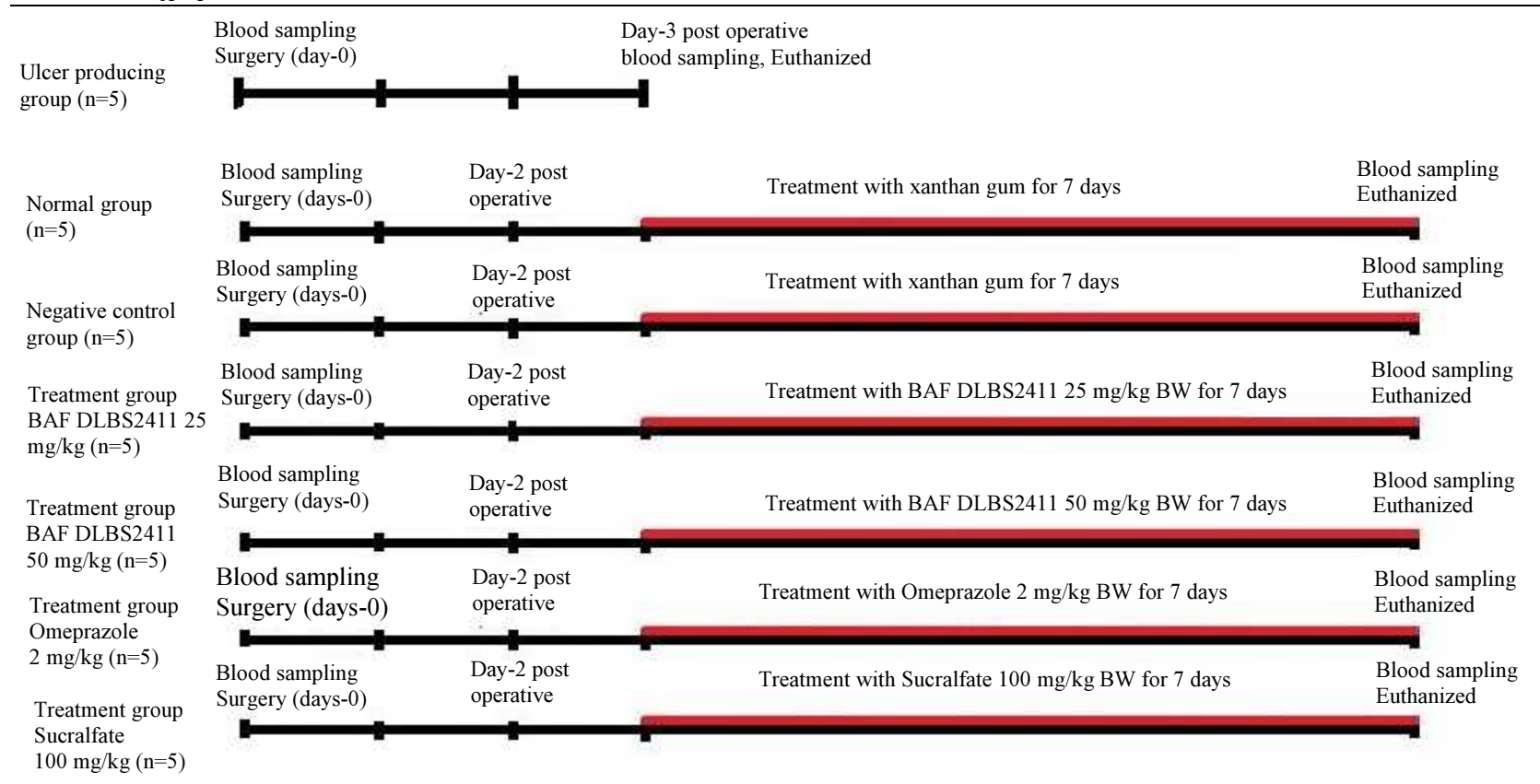

Fig. 1: Timeline experimental

\section{Histopathology Examination}

At the end of the treatment, the animals were euthanized. Gastric samples were collected and fixed into neutral buffer formalin. These samples were processed using tissue processor with different concentrations of ethanol and stained with hematoxylin eosin and examined under $10 \times$ magnification.

Severity of gastric ulcer was assessed according to the method by Karakoyun et al. (2009) where the result of the examination was divided into four parameters which are desquamation of surface epithelium (0-3), hemorrhage, focal necrosis and mucosal congestion $(0-$ $3)$, glandular cells degeneration (0-3) and inflammatory cell infiltration (0-3) with a maximum total score of 12 for the most severe condition.

Wound healing process was categorized into three categories: No granulation tissue (score 0), thin granulation tissue (score 1), mild granulation tissue (score 2) and thick granulation tissue (score 3) (Gunal et al., 2002).

\section{Statistical Analysis}

Data of each group should be normally distributed and the variance should be homogenous in order to be analyzed with one-way analysis of variance (ANOVA). The continuous data were expressed as mean \pm S.E.M. (standard error of mean) followed by post hoc test for multiple comparisons (Tukey's HSD or Games-Howell test), using SPSS ${ }^{\circledR} 20$ Statistics software. Throughout the analysis, parametric variables were $\log$ transformed in order to meet the underlying distributional assumptions of the statistical models otherwise, the corresponding nonparametric test results were used. All statistical tests were done at $5 \%$ level of significance considered as statistically significant.

\section{Results}

\section{Pilot Study (Ulcer Producing Study)}

A pilot study was performed prior to the full study of DLBS2411 on acetic acid-induced ulceration. The purpose of this pilot study was to determine whether acetic acid $(80 \% \mathrm{v} / \mathrm{v}, 500 \mu \mathrm{L})$ could induce gastric ulcer on the mucous layer. Pathology and histopathology examination showed that the treatment successfully induced gastric ulcer as shown in Fig. 2.

From the histopathology examination, it was apparent that edema and hemorrhagia with a lot of neutrophils infiltration were found in all groups of the ulcer producing study (Fig. 2B). Neutrophils were found in the serosa area and spreading to the mucosa of gastric. According to these results, contact with acetic acid $(80 \%$ $\mathrm{v} / \mathrm{v}, 500 \mu \mathrm{L}$ ) was able to induce the ulcer formation successfully. Therefore, this method was valid for further study, i.e., induction of ulcerations.

\section{Full Study}

Following the pilot study, a full study investigating the effect of DLBS2411 on gastric ulcers were performed. Figure 3 shows that the biggest ulceration was seen in untreated animals, as compared to treatment and positive control groups. 


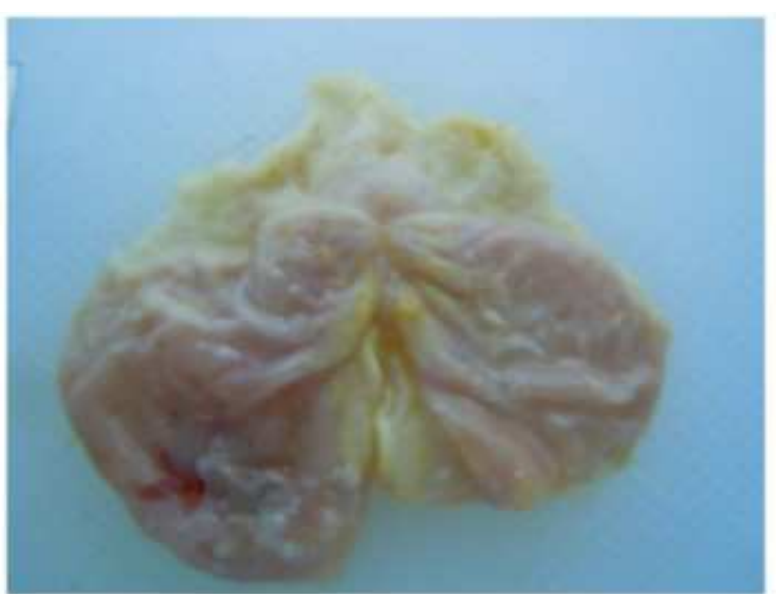

(A)

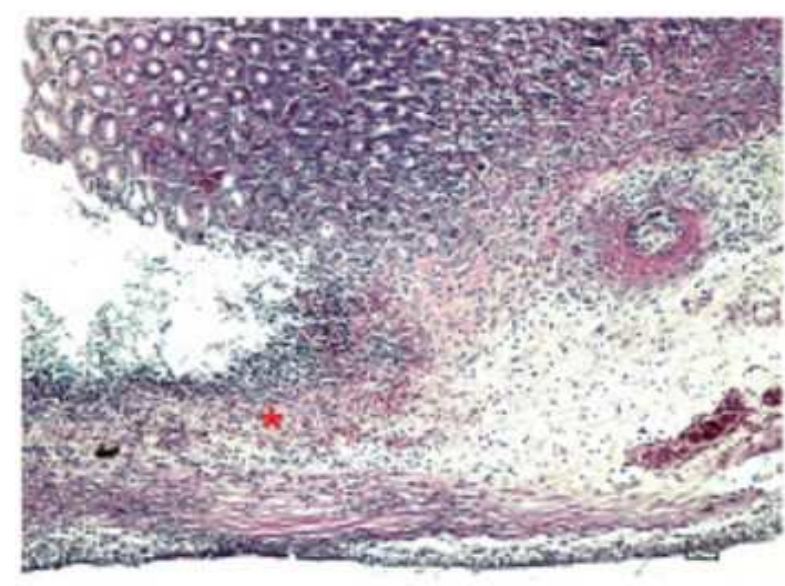

(B)

Fig. 2: Result from Ulcer Producing Study; A. Pathology condition of gastric ulcer, B. Histopathology condition

A

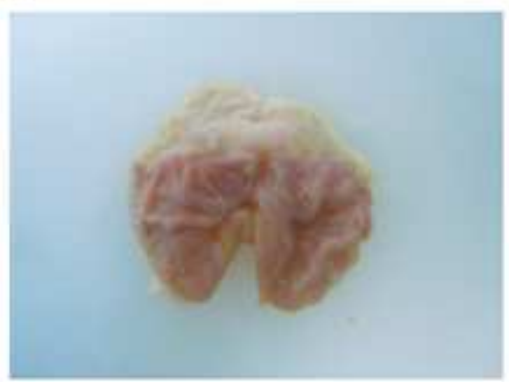

D

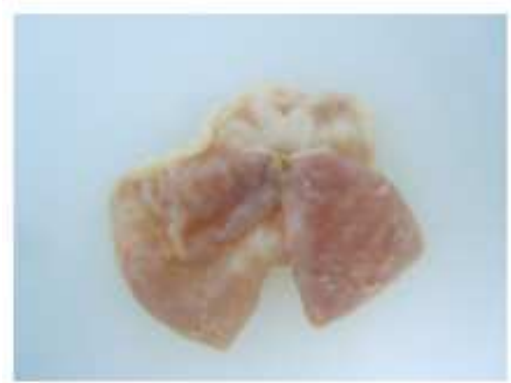

B

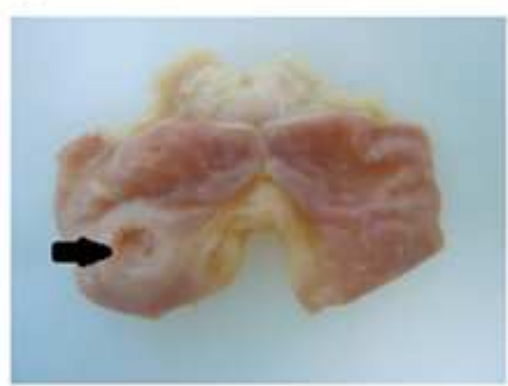

$\mathrm{E}$

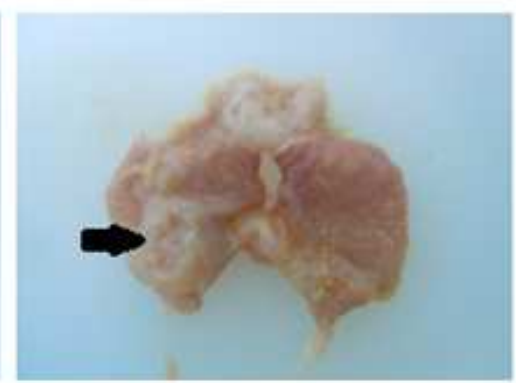

C

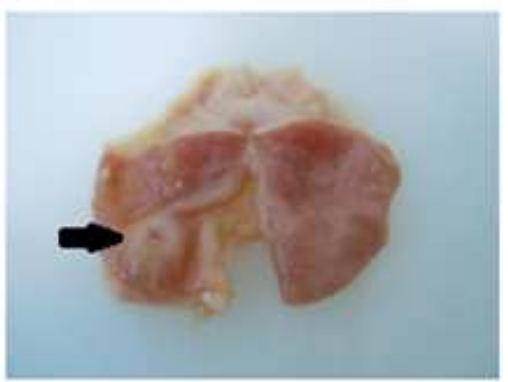

F

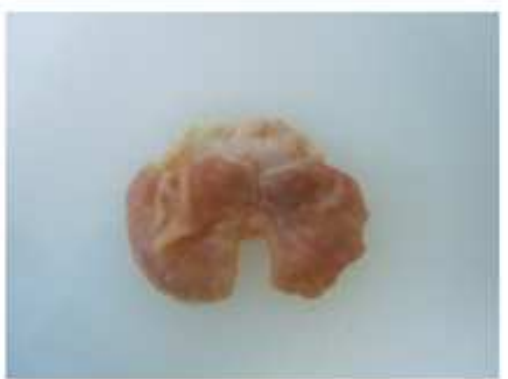

Fig. 3: Pathology of gastric after treatment; A. Healthy animals, B. Untreated animals, C. Treatment Group BAF DLBS2411 $25 \mathrm{mg}$ $\mathrm{kg}^{-1}$ BW, D. Treatment Group BAF DLBS2411 $50 \mathrm{mg} \mathrm{kg}^{-1}$ BW, E. Positive Control Group I (Omeprazole) F. Positive Control Group II (Sucralfate). The scale of each picture is the same

All groups except the healthy animals developed ulceration, with the untreated animals forming the most severe ulceration with an area that reached $53-172 \mathrm{~mm}^{2}$ and approximately $3 \mathrm{~mm}$ depth. The other treatment groups and positive control showed less severe ulceration (BAF DLBS2411 $25 \mathrm{mg} \mathrm{kg}^{-1}, 50 \mathrm{mg} \mathrm{kg}^{-1}$, omeprazole and sucralfate which reached the area of 2273, 0-172, 2-189 and 0-165 $\mathrm{mm}^{2}$ respectively) compared to the untreated animals.
Histopathology examination showed the presence of edema and hemorrhage in the untreated animals. Macrophages mixed with neutrophils were also found in the cytoplasm from the serosa to submucosa area in dark brown color (hemosiderin). Details of mucus formation and the severity of gastric ulcer were determined through histopathology examination as shown in Fig. 4, while ulcer area of each group is shown in Fig. 5. 


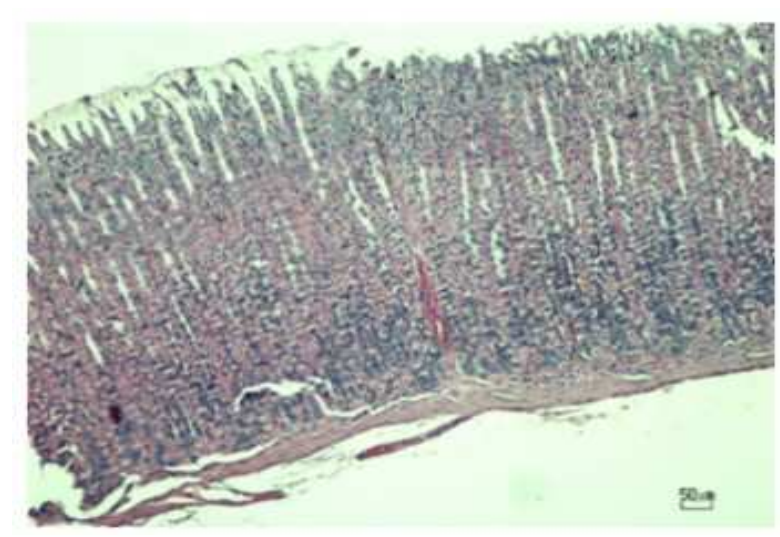

(A)
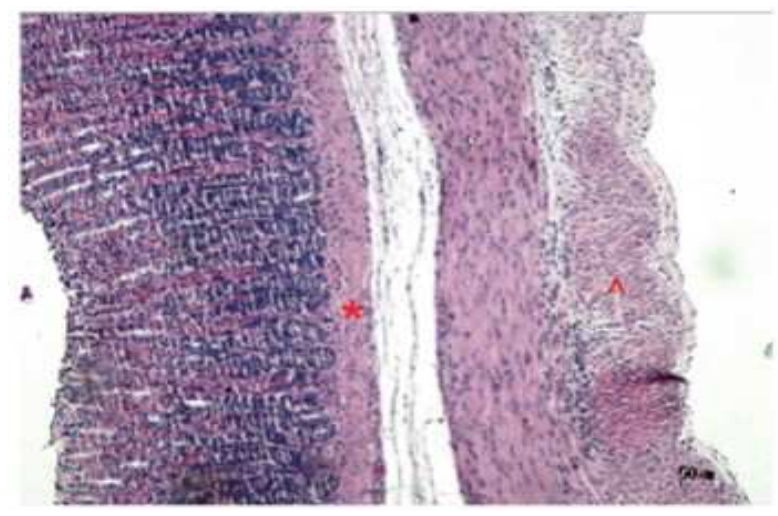

(C)

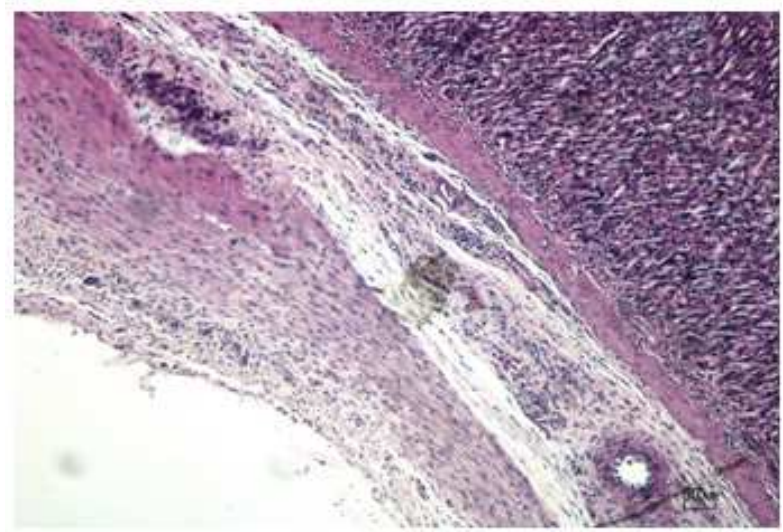

(E)

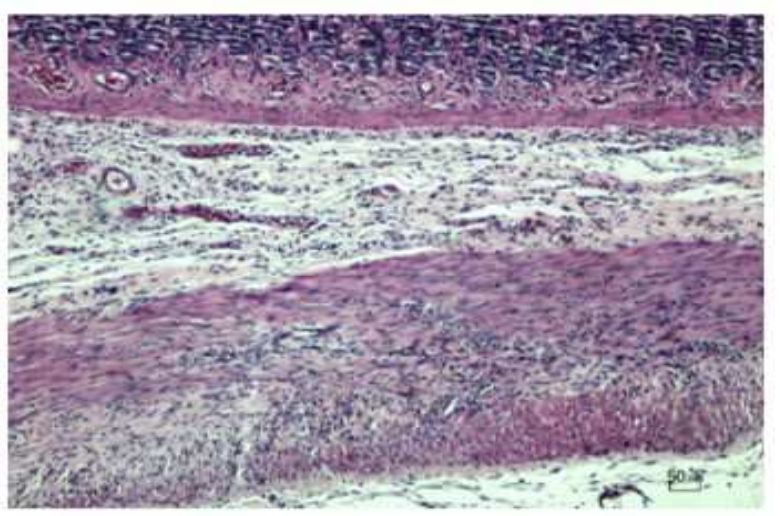

(B)

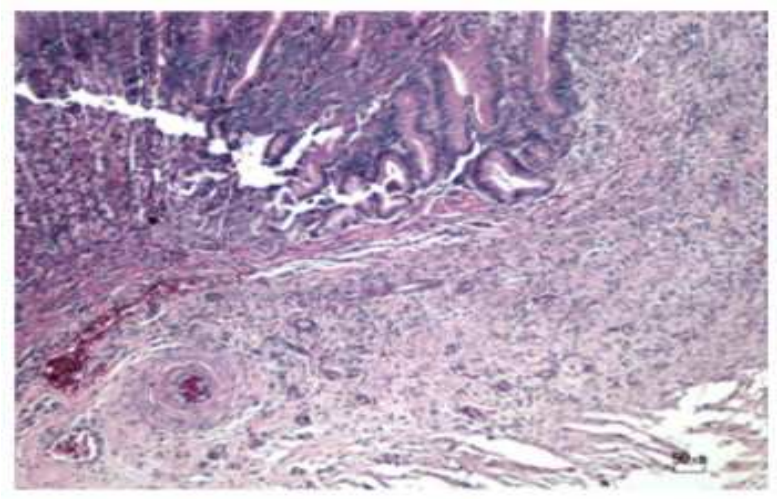

(D)

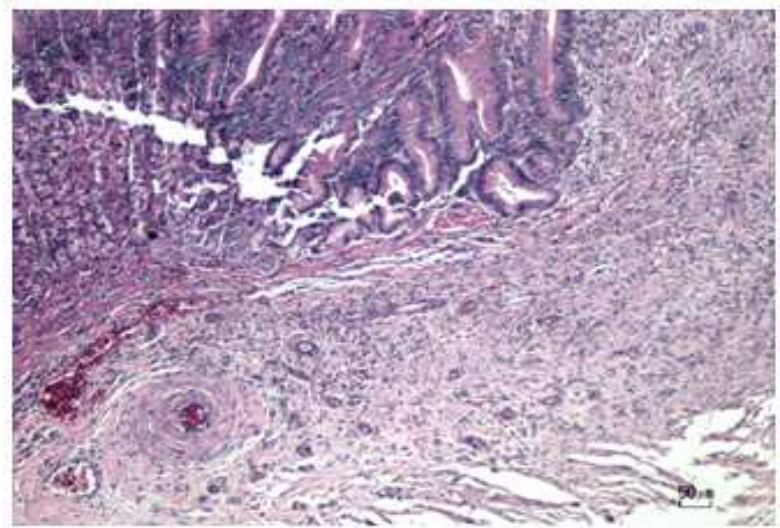

(F)

Fig. 4: Histopathology examination; A. Healthy Animals, B. Untreated animals, C. Treatment group BAF DLBS2411 $25 \mathrm{mg} \mathrm{kg}^{-1}$ BW, D. Treatment Group BAF DLBS2411 $50 \mathrm{mg} \mathrm{kg}^{-1}$ BW, E. Positive Control group I (Omeprazole), F. Positive Control group II (Sucralfate). Magnification $\times 10$

Based on the histopathology results, there was no abnormal condition observed in the healthy animals (Fig. 4A). Untreated animals developed severe infiltration of lymphocytes, plasma cell, macrophages mixed with a fewer numbers of neutrophils, eosinophils and mast cells in the serous and mucous layer of gastric. A number of brown-pigmented macrophages were also found in the cytoplasm (Fig. 4B). Treatment groups of BAF DLBS2411 at dose of 25 and $50 \mathrm{mg} \mathrm{kg}^{-1}$ BW showed segmented erosion on the mucosal surface (Fig. 4C and D). Overall mucous muscular and serous areas were found to be thickened by granular tissues. Omeprazole-treated group showed a segmented edema and capillary dilatation on the submucous and muscular 
mucous areas which led to the development of edema thickening, mononuclear cell infiltration and granular tissues in the serous area (Fig. 4E). Mild to moderate macrophage infiltration mixed with eosinophils were also found. Fibrous tissues mixed with severe infiltration were found on the gastric serosa and mucous of the sucralfate-treated group (Fig. 4F). Vasculitis was also found on the submucous area of this group (Fig. 4F).
Treatment with BAF DLBS2411 at dose of $25 \mathrm{mg}$ $\mathrm{kg}^{-1}, 50 \mathrm{mg} \mathrm{kg}^{-1}$ and sucralfate reduced the gastric ulcer area up to $54.8,36.53$ and $14.85 \%$, respectively, compared to that of the untreated animals (Fig. 5). While treatment with omeprazole for 7 days did not cause any marked reduction of the gastric ulcer size from that of the untreated animals (Table 1).

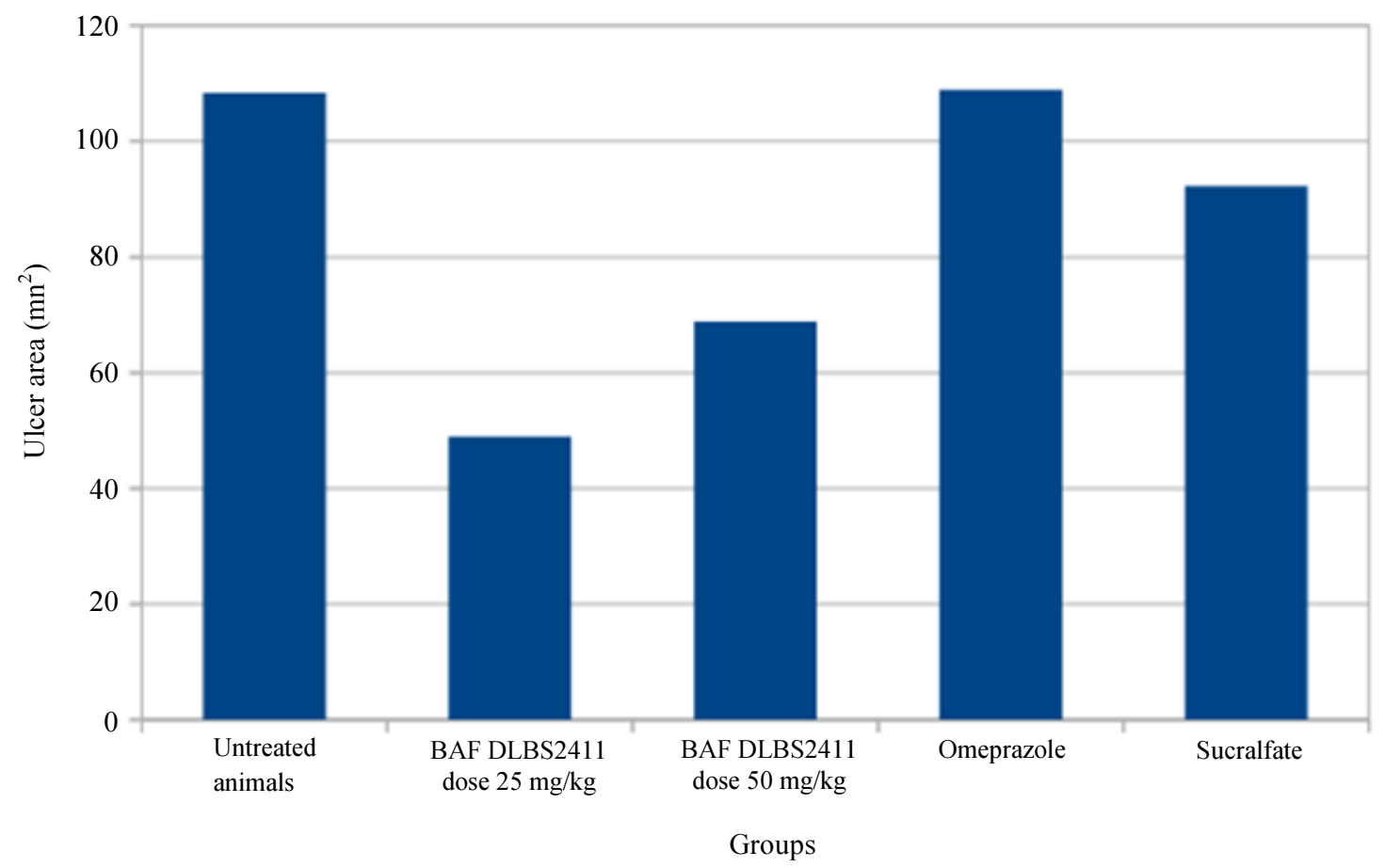

Fig. 5: Ulcer area

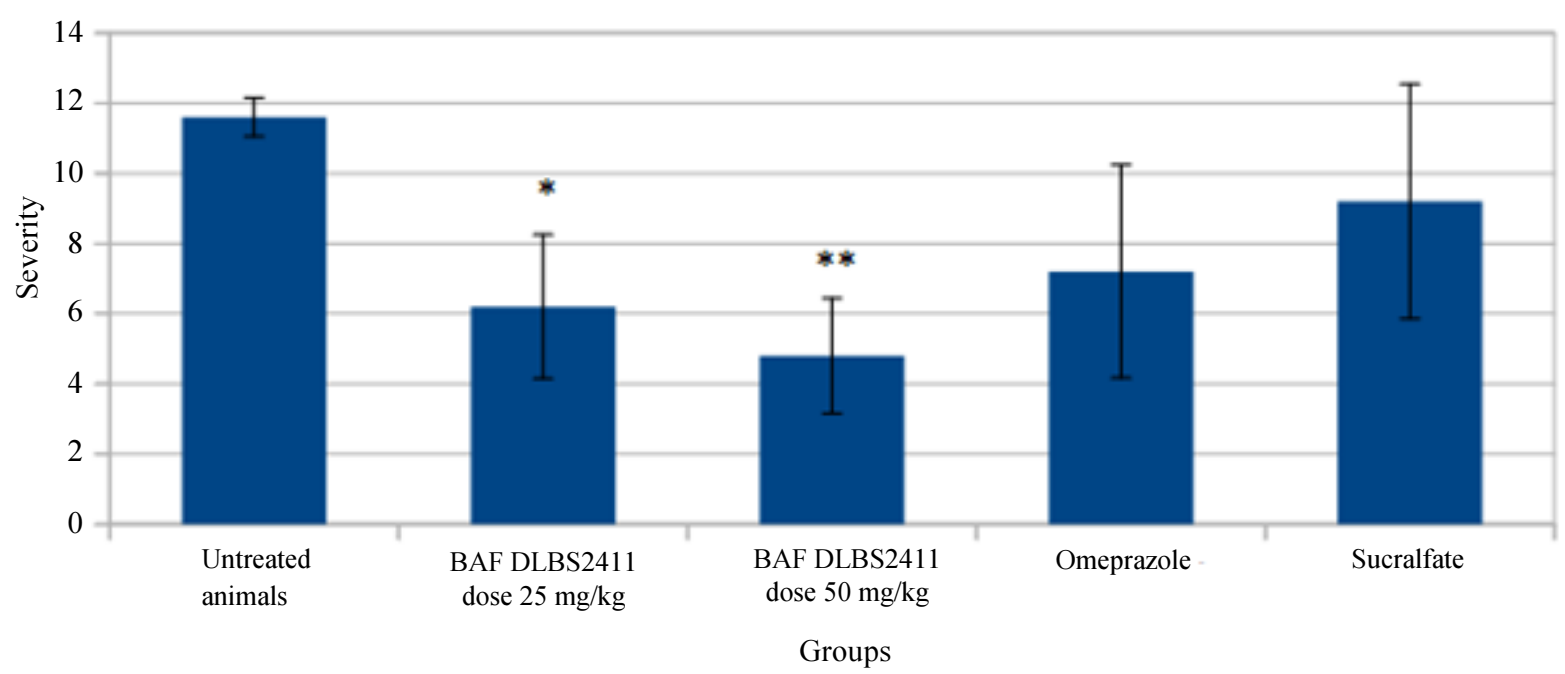

Fig. 6: Semi-quantitative assessment of the gastric ulcer severity according to Karakoyun et al. (2009). Four parameters examined were desquamation of surface epithelium (scoring 0-3), hemorrhage, focal necrosis and mucosal congestion (scoring 0-3), glandular cells degeneration (scoring 0-3), and inflammatory cell infiltration (scoring 0-3) with a maximum total score of 12 for the most severe condition. ${ }^{*}: \mathrm{p}<0.05$ versus untreated animals. ${ }^{*}: \mathrm{p}<0.01$ versus untreated animals 


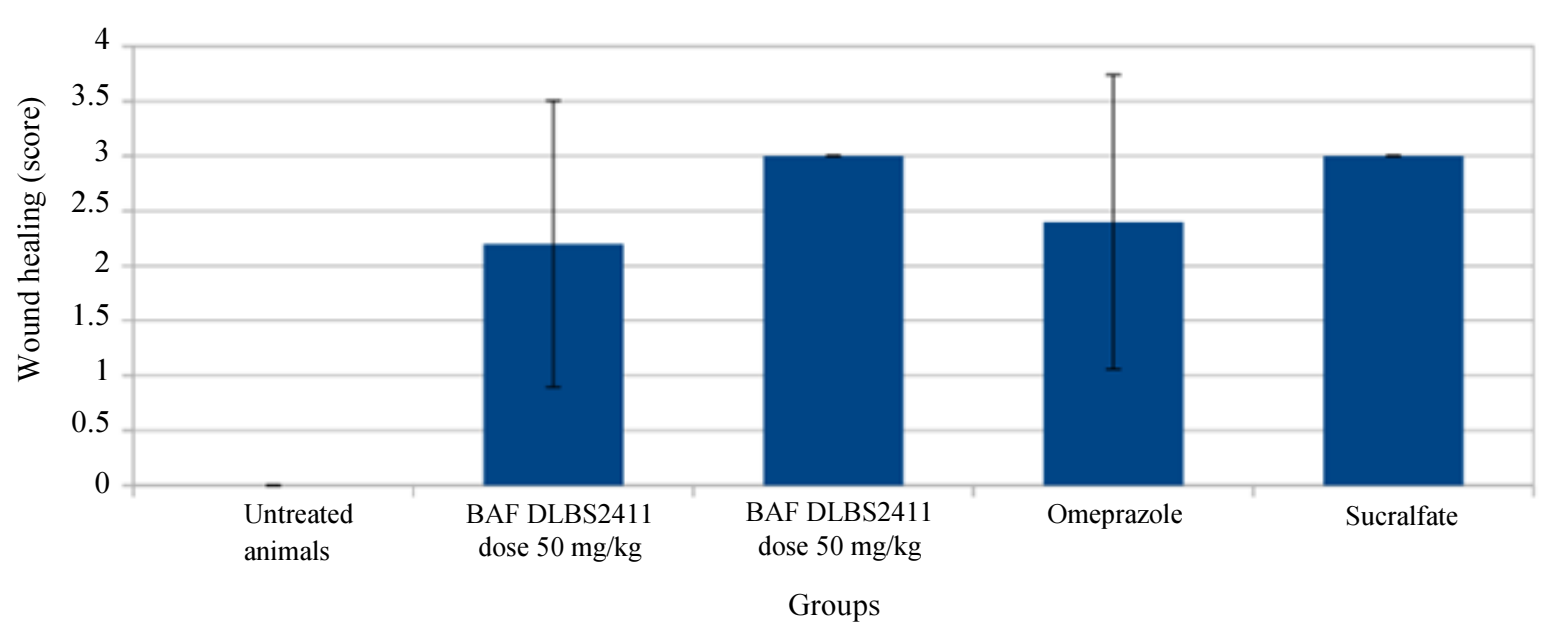

Fig. 7: Wound healing process. Healing process was examined based on histopathology examination

Table 1: Ulcer area

\begin{tabular}{llcccc}
\hline & Ulcer area $\left(\mathrm{mm}^{2}\right)$ & & & \\
Group & - & & & \\
& $\mathrm{N}$ & Mean & Std. Deviation & Minimum & Maximum \\
\hline Normal & 5 & - & - & - & - \\
Negative Control & 5 & 108.4 & 48.9 & 56.0 & 160.5 \\
DLBS2411 $25 \mathrm{mg} \mathrm{kg}^{-1} \mathrm{BW}$ & 5 & 49.0 & 21.0 & 22.0 & 71.5 \\
DLBS2411 $50 \mathrm{mg} \mathrm{kg}^{-1} \mathrm{BW}$ & 5 & 68.8 & 72.9 & 0.0 & 171.5 \\
Omeprazole $2 \mathrm{mg} \mathrm{kg}^{-1} \mathrm{BW}$ & 5 & 108.9 & 72.0 & 2.0 & 188.5 \\
Sucralfate $100 \mathrm{mg} \mathrm{kg}^{-1} \mathrm{BW}$ & 5 & 92.3 & 63.8 & 0.0 & 162.5 \\
\hline
\end{tabular}

There was no ulcer developed in the Healthy Animals

Table 2: Ulcer severity

Ulcer severity score

\begin{tabular}{llccrr} 
Group & $\mathrm{N}$ & Mean & Std. Deviation & Minimum & Maximum \\
\hline Normal & 5 & - & - & - \\
Negative Control & 5 & 11.6 & 0.5 & 11 & 12 \\
DLBS2411 $25 \mathrm{mg} \mathrm{kg}^{-1} \mathrm{BW}$ & 5 & $6.2^{*}$ & 2.0 & 4 & 8 \\
DLBS2411 $50 \mathrm{mg} \mathrm{kg}^{-1} \mathrm{BW}$ & 5 & $4.8^{* *}$ & 1.6 & 3 & 7 \\
Omeprazole $2 \mathrm{mg} \mathrm{kg}^{-1} \mathrm{BW}$ & 5 & 7.2 & 3.0 & 3 & 10 \\
Sucralfate $100 \mathrm{mg} \mathrm{kg}^{-1} \mathrm{BW}$ & 5 & 9.2 & 3.3 & 4 & 12 \\
\hline
\end{tabular}

There was no ulcer developed in the Healthy Animals. *: $\mathrm{p}<0.05$ versus Negative Control. ${ }^{* *}$ : $\mathrm{p}<0.01$ versus Negative Control.

Histopathology data showed that under normal condition (i.e., the healthy animals), rats did not develop any ulcer. The most severe gastric ulcers were found in the untreated animals. Treatment groups of BAF DLBS2411 at dose of $25 \mathrm{mg} \mathrm{kg}$, omeprazole and sucralfate developed only mild to moderate gastric ulcers. Small ulcers were found in BAF DLBS2411 at dose of $50 \mathrm{mg} \mathrm{kg}^{-1}$ group. A semi-quantitative severity scoring data according to the method developed by Karakoyun et al. (2009) is shown in Fig. 6.
Wound healing process was scored based on granulation in tissues developed in gaster following treatments. Based on the observation, treatment with DLBS2411 at doses 25 and $50 \mathrm{mg} \mathrm{kg}^{-1}$ were found to produce only mild to thick granulation, which were similar to that of omeprazole and sucralfate (Fig. 7). Treatment with BAF DLBS2411 at dose of $25 \mathrm{mg} \mathrm{kg}^{-1}$, $50 \mathrm{mg} \mathrm{kg}{ }^{-1}$ and positive control group treated with omeprazole and sucralfate reduced the severity of gastric ulcer as much as $45,56.67,36.67$ and $20 \%$, respectively, compared to that of the untreated animals (Table 2). 
Table 3: Hematology before treatment

\begin{tabular}{|c|c|c|c|c|c|c|c|}
\hline \multirow[b]{5}{*}{ Description } & \multirow{2}{*}{\multicolumn{3}{|c|}{ Pilot study }} & \multicolumn{4}{|l|}{ Full study } \\
\hline & & & & \multicolumn{2}{|c|}{ Treatment group } & \multicolumn{2}{|c|}{ Positive control group } \\
\hline & Ulcer & Normal & Negative & BAF & BAF & & \\
\hline & Producing & Control & Control & DLBS2411 & DLBS2411 & Omeprazole & Sucralfate \\
\hline & Group & Group & Group & $25 \mathrm{mg} / \mathrm{kg}$ & $50 \mathrm{mg} / \mathrm{kg}$ & $2 \mathrm{mg} / \mathrm{kg}$ & $100 \mathrm{mg} / \mathrm{kg}$ \\
\hline $\mathrm{WBC}\left(\mathrm{x} 10^{6} / \mu \mathrm{L}\right)$ & $8.4 \pm 2.7$ & $9.394 \pm 1.75$ & $8.55 \pm 2.60$ & $9.48 \pm 1.56$ & $10.4 \pm 2.76$ & $8.8 \pm 1.29$ & $10.28 \pm 1.59$ \\
\hline $\mathrm{RBC}\left(\times 10^{6} / \mu \mathrm{L}\right)$ & $8.087 \pm 0.33$ & $7.933 \pm 0.95$ & $8.376 \pm 0.56$ & $8.187 \pm 0.41$ & $8.233 \pm 0.70$ & $8.724 \pm 0.49$ & $8.376 \pm 0.31$ \\
\hline $\operatorname{HGB}(\mathrm{g} / \mathrm{dL})$ & $16.09 \pm 0.17$ & $15.21 \pm 1.28$ & $16.23 \pm 0.74$ & $16.13 \pm 1.02$ & $16.09 \pm 1.20$ & $16.37 \pm 0.87$ & $16.42 \pm 1.02$ \\
\hline $\operatorname{HCT}(\%)$ & $44.03 \pm 0.66$ & $42.25 \pm 3.34$ & $44.18 \pm 1.75$ & $43.81 \pm 2.36$ & $43.79 \pm 3.47$ & $45.35 \pm 2.33$ & $44.88 \pm 2.86$ \\
\hline Platelet $\left(\times 10^{6} / \mu \mathrm{L}\right)$ & $764.6 \pm 126.01$ & $747.7 \pm 268.99$ & $783.4 \pm 48.10$ & $878.7 \pm 205.42$ & $816 \pm 48.53$ & $737.7 \pm 60.52$ & $786.9 \pm 69.03$ \\
\hline $\mathrm{MCV}(\mathrm{fL})$ & $54.49 \pm 1.75$ & $53.53 \pm 3.26$ & $52.83 \pm 2.04$ & $53.5 \pm 1.01$ & $53.2 \pm 1.26$ & $52 \pm 1.62$ & $53.56 \pm 2.14$ \\
\hline $\mathrm{MCH}(\rho g)$ & $19.92 \pm 0.64$ & $19.27 \pm 1.12$ & $19.41 \pm 0.85$ & $19.7 \pm 0.65$ & $19.56 \pm 0.57$ & $18.77 \pm 0.59$ & $19.61 \pm 0.93$ \\
\hline $\mathrm{MCHC}(\mathrm{g} / \mathrm{dL})$ & $36.54 \pm 0.47$ & $36.03 \pm 1.39$ & $36.74 \pm 0.59$ & $36.81 \pm 0.83$ & $36.76 \pm 0.43$ & $36.09 \pm 0.69$ & $36.6 \pm 0.68$ \\
\hline RDW (\%) & $11.45 \pm 0.40$ & $12.1 \pm 0.64$ & $11.71 \pm 0.78$ & $12.25 \pm 0.78$ & $11.95 \pm 0.79$ & $11.75 \pm 0.27$ & $11.68 \pm 0.35$ \\
\hline РCT (\%) & $0.296 \pm 0.05$ & $0.282 \pm 0.08$ & $0.277 \pm 0.03$ & $0.328 \pm 0.11$ & $0.277 \pm 0.02$ & $0.264 \pm 0.03$ & $0.278 \pm 0.04$ \\
\hline MPV (fL) & $3.89 \pm 0.35$ & $4.07 \pm 1.27$ & $3.54 \pm 0.38$ & $3.65 \pm 0.37$ & $3.39 \pm 0.14$ & $3.58 \pm 0.25$ & $3.55 \pm 0.29$ \\
\hline PDW (\%) & $15.17 \pm 0.50$ & $15.49 \pm 0.74$ & $14.99 \pm 0.31$ & $15.6 \pm 0.92$ & $14.89 \pm 0.20$ & $15.2 \pm 0.18$ & $14.93 \pm 0.43$ \\
\hline
\end{tabular}

Table 4: Hematology after treatment

\begin{tabular}{|c|c|c|c|c|c|c|c|}
\hline \multirow[b]{5}{*}{ Description } & \multirow{2}{*}{\multicolumn{3}{|c|}{ Pilot Study }} & \multicolumn{4}{|l|}{ Full Study } \\
\hline & & & & \multicolumn{2}{|l|}{ Treatment Group } & \multicolumn{2}{|c|}{ Positive Control Group } \\
\hline & Ulcer & Normal & Negative & BAF & BAF & & \\
\hline & Group & Control & Control & DLBS2411 & DLBS2411 & Omeprazole & Sucralfate \\
\hline & Producing & Group & Group & $25 \mathrm{mg} / \mathrm{kg}$ & $50 \mathrm{mg} / \mathrm{kg}$ & $2 \mathrm{mg} / \mathrm{kg}$ & $100 \mathrm{mg} / \mathrm{kg}$ \\
\hline WBC (x10 $/ \mu \mathrm{L})$ & $9.58 \pm 1.49$ & $10.51 \pm 1.66$ & $10.8 \pm 2.21$ & $10.69 \pm 3.17$ & $12.88 \pm 1.37$ & $9.68 \pm 3.82$ & $11.56 \pm 1.98$ \\
\hline $\mathrm{RBC}\left(\mathrm{x} 10^{6} / \mu \mathrm{L}\right)$ & $6.931 \pm 0.53$ & $7.934 \pm 0.39$ & $7.792 \pm 0.70$ & $7.42 \pm 0.55$ & $7.754 \pm 0.54$ & $7.56 \pm 0.61$ & $7.642 \pm 0.37$ \\
\hline $\operatorname{HGB}(\mathrm{g} / \mathrm{dL})$ & $14.37 \pm 0.68$ & $15.03 \pm 0.66$ & $14.97 \pm 0.79$ & $14.37 \pm 1.33$ & $15.01 \pm 0.77$ & $14.28 \pm 0.96$ & $15.03 \pm 0.38$ \\
\hline $\operatorname{HCT}(\%)$ & $38.78 \pm 1.76$ & $41.9 \pm 2.16$ & $41.31 \pm 3.02$ & $39.68 \pm 3.68$ & $41.15 \pm 2.80$ & $40.48 \pm 2.35$ & $41.29 \pm 0.90$ \\
\hline Platelet $\left(\times 10^{6} / \mu \mathrm{L}\right)$ & $713.4 \pm 74.33^{\mathrm{b}, \mathrm{d}, \mathrm{e}, \mathrm{f}, \mathrm{g}}$ & $1074.7 \pm 90.95^{\mathrm{a}}$ & $900.4 \pm 191.81$ & $1008.8 \pm 102.57^{\mathrm{a}}$ & $1058 \pm 156.07^{\mathrm{a}}$ & $1071.40 \pm 118.12^{\mathrm{a}}$ & $1064 \pm 153.29^{\mathrm{a}}$ \\
\hline $\mathrm{MCV}(\mathrm{fL})$ & $56.14 \pm 3.41$ & $52.84 \pm 1.85$ & $53.12 \pm 2.02$ & $53.38 \pm 1.64$ & $53.06 \pm 0.50$ & $52.92 \pm 3.21$ & $54.11 \pm 2.19$ \\
\hline $\mathrm{MCH}(\rho \mathrm{g})$ & $20.79 \pm 1.40^{\mathrm{b}, \mathrm{f}}$ & $18.95 \pm 0.71^{\mathrm{a}}$ & $19.27 \pm 0.85$ & $19.32 \pm 0.54$ & $19.39 \pm 0.66$ & $18.66 \pm 0.77$ & $19.7 \pm 0.81$ \\
\hline $\mathrm{MCHC}(\mathrm{g} / \mathrm{dL})$ & $37.05 \pm 0.47$ & $35.89 \pm 0.32$ & $36.29 \pm 1.02$ & $36.17 \pm 0.67$ & $36.53 \pm 1.04$ & $35.32 \pm 1.44$ & $36.41 \pm 0.59$ \\
\hline RDW (\%) & $12.58 \pm 0.88$ & $12.28 \pm 0.39$ & $12.03 \pm 0.28$ & $12.22 \pm 0.20$ & $11.95 \pm 0.09$ & $12.96 \pm 1.69$ & $12.32 \pm 0.55$ \\
\hline PCT (\%) & $0.268 \pm 0.03^{b, f, g}$ & $0.401 \pm 0.05^{\mathrm{a}}$ & $0.337 \pm 0.08$ & $0.382 \pm 0.07$ & $0.374 \pm 0.07$ & $0.42 \pm 0.03$ & $0.396 \pm 0.06^{\mathrm{a}}$ \\
\hline MPV (fL) & $3.8 \pm 0.39$ & $3.74 \pm 0.34$ & $3.71 \pm 0.26$ & $3.75 \pm 0.40$ & $3.52 \pm 0.14$ & $3.92 \pm 0.20$ & $3.72 \pm 0.14$ \\
\hline PDW (\%) & $15.31 \pm 0.45$ & $14.82 \pm 0.71$ & $15.25 \pm 0.64$ & $15.67 \pm 0.53$ & $15.07 \pm 0.46$ & $15.07 \pm 1.03$ & $15.33 \pm 0.50$ \\
\hline
\end{tabular}

a) $\mathrm{p}<0.05$ Vs ulcer producing group, b) $\mathrm{p}<0.05$ vs Healthy Animals, c) $p<0.05$ Vs Untreated Animals

d) $\mathrm{p}<0.05$ Vs treatment group with BAF DLBS2411 at dose $25 \mathrm{mg} \mathrm{kg}^{-1} \mathrm{BW}$

e) $p<0.05 \mathrm{Vs}$ treatment group with BAF DLBS2411 at dose $50 \mathrm{mg} \mathrm{kg}^{-1} \mathrm{BW}$

f) $\mathrm{p}<0.05 \mathrm{Vs}$ positive control group omeprazole at dose $2 \mathrm{mg} \mathrm{kg}^{-1} \mathrm{BW}$

g) $\mathrm{p}<0.05 \mathrm{Vs}$ positive control group sucralfate at dose $100 \mathrm{mg} \mathrm{kg}^{-1} \mathrm{BW}$

Hematology examination before treatment showed that prior to the study the animals were in excellent condition. The result of hematology examination after treatment were found to be significantly different on the platelet, $\mathrm{MCH}$ and PCT value of ulcer producing group due to time differences between pilot study and full study which was performed on day- 3 and day-10 after induction of gastric ulcer. There was no significant difference in the hematological value among groups on full study (Table 3 and 4). This result indicates that all treatment agents did not affect the hematological value.

\section{Discussion}

Previous study by Gunal et al. (2002) has documented that several evidence showing acetic acid-induced gastric ulcer becomes chronic within 2-3 days and heals completely within 2-3 weeks without perforation or penetration. The ulcer induced by acetic acid is assumed to be similar to that of chronic human ulcer with regards to its location, severity and chronicity as well as with regard to the healing process (Silva et al., 2013). 
Treatment with BAF DLBS2411 at doses of $25 \mathrm{mg}$ $\mathrm{kg}^{-1}, 50 \mathrm{mg} \mathrm{kg}^{-1}(\mathrm{BW})$ and sucralfate reduced the gastric ulcer area up to $54.8,36.53$ and $14.85 \%$, respectively, from that of the untreated animals. Treatment with omeprazole for 7 days, however, did not indicate any reduction of the ulcer area. The severity of the ulcer was improved in all treated groups: treatment group DLBS2411 $25 \mathrm{mg} \mathrm{kg}^{-1} \mathrm{BW}$, DLBS2411 $50 \quad \mathrm{mg}^{-1} \mathrm{~kg}$, omeprazole and sucralfate, as compared to that of the untreated animals. The severity scoring for gastric ulcer was determined by histopathology examination.

Untreated animals had the most severe damage among the groups; while the treated groups such as treatment group DLBS2411 at dose of $25 \mathrm{mg} \mathrm{kg}^{-1}$ $\mathrm{BW}$, omeprazole and sucralfate developed mild to moderate gastric ulcers. The mildest ulceration was developed in treatment group DLBS2411 at dose of 50 $\mathrm{mg} \mathrm{kg}^{-1} \mathrm{BW}$. Treatment with DLBS2411 at dose of 25 and $50 \mathrm{mg} \mathrm{kg}$, omeprazole and sucralfate could reduce the severity of gastric ulcer as much as 45 , $56.67,36.67$ and $20 \%$, respectively, compared to the untreated animals. Severity of gastric injury was assessed semi-quantitatively using method from Karakoyun et al. (2009) where each measured parameter was categorized into $0-3$, resulting a maximum total score of 12, as shown in Fig. 6.

The reduction of ulcer area and alleviation of ulcer severity based on the histopathology analyses indicated that DLBS2411 treatments, either at the dose of 25 or 50 $\mathrm{mg} \mathrm{kg} \mathrm{kg}^{-1} \mathrm{BW}$ in rats, were comparable to those of omeprazole or sucralfate. This may have occurred due to the dual mechanisms of action of DLBS2411: A down-regulator of proton pump and a mucosal protective agent (Tjandrawinata et al., 2013). Extensive studies have been carried out to assess the pharmaceutical potential of $C$. burmannii. Several studies have shown its potential effect as antibacterial, anti-inflammatory and analgesic drug (Al-Dhubiab, 2012; Khatib et al., 2005; Wu and Chou, 2011).

DLBS2411 treatment is known to elevate phosphorylation of IKK and activate nuclear factor-KB (NF-KB) which could stimulate mucus synthesis and mucosal blood flow. High level of NF-KB increased mucus synthesis by promoting cyclooxygenase- 2 (COX-2) and $\mathrm{PGE}_{2}$ expression, which increased the MUC5AC gene. Activation NF-KB also increased production of NO, which stimulated mucosal blood flow (Wulandari et al., 2016). These mechanisms of action are postulated to provide the basis of the healing process of gastric ulcer by C. burmannii. A number of clinical trials are currently in process to investigate the efficacy and safety of DLBS2411 as treatment for gastric ulcer patients (identified number NCT01573403 and NCT02262169 respectively).

\section{Conclusion}

From the result of the present study, DLBS2411 at dose of 25 and $50 \mathrm{mg} \mathrm{kg}^{-1} \mathrm{BW}$ were effective for gastric ulcer treatment as measured by the reduction of ulcer size. It is also effective in alleviating ulcer severity as seen from the histopathology result. There was no significant difference in hematological value among groups in the full study, indicating that DLBS2411 did not affect hematology profile. This present study demonstrated that DLBS2411 at dose of 25 and $50 \mathrm{mg} \mathrm{kg}^{-1} \mathrm{BW}$ (or equivalent to the human dose of 250 and $500 \mathrm{mg}$ daily) demonstrated curative effect on acetic-induced gastric ulcer.

\section{Acknowledgement}

The authors would like to thank PT Dexa Medica for funding this research. The authors would also like to thank Irfan A. Darfiansyah, Arfken Andi, Marissa Winata and Treesye AS Wijaya for the preparation of DLBS2411, Dicky Ari Wibowo and Lita Tuentifiany for the animal operating procedures, Neny Agustianingsih and Dewi Andriani for daily animal care, Bambang Veriansyah, Imelda L. Winoto and Hanna C. Rouli for thorough review of this manuscript.

\section{Author Contributions}

Raymond Rubianto Tjandrawinata and Florensia Nailufar: Were both responsible for the design of this study, execution of the experimentation and analytical evaluation of the study.

\section{Funding Information}

This research is funded by PT Dexa Medica.

\section{Conflict of Interest}

The authors declare that they have no conflict of interest.

\section{References}

Al-Dhubiab, B.E., 2012. Pharmaceutical applications and phytochemical profile of Cinnamomum burmannii. Pharmacogn Rev., 6: 125-131. DOI: 10.4103/0973-7847.99946

Bae, D.K., D. Park, S.H. Lee, G. Yang and Y.Y.H. Kim et al., 2011. Different antiulcer activities of Pantoprazole in Stress, Alcohol and Pylorus Ligation-Induced ulcer models. Lab. Anim. Res., 27: 47-52. DOI: $10.5625 /$ lar.2011.27.1.47

Dallwig, B., 2010. Therapeutic review sucralfate. J. Exotic Pet Med., 19: 101-104. DOI: $10.1053 /$ j.jepm.2010.01.011 
De Barros, M.P., M. Lemos, E.L. Maistro, M.F. Leite and J.P.B. Sousa et al., 2008. Evaluation of antiulcer activity of the main phenolic acids found in Brazilian Green Propolis. J. Ethnopharmacol., 120: 372-377. DOI: 10.1016/j.jep.2008.09.015

Gunal, O., B.K. Oktar, E. Ozcinar, D. Tansuker and S. Arbak et al., 2002. Healing-promoting effect of bombesin treatment on chronic gastric ulcer in rats. Regulatory Peptides, 106: 81-88. DOI: 10.1016/S0167-0115(02)00055-1

Karakoyun, B., M. Yuksel, F. Ercan, C. Erzik and B.C. Yegen, 2009. Alpha-lipoic acid improves acetic acid-induced gastric ulcer healing in rats. Inflammation, 32: 37-46.

DOI: $10.1007 / \mathrm{s} 10753-008-9100-4$

Kartolo, D., R.R. Tjandrawinata, E. Suparman, L.W. Susanto and E. Suparman, 2016. Clinical experience with DLBS3233, a combination of cinnamommum burmannii and lagerstroemia speciosa, for polycystic ovary syndrome treatment. Asian J. Pharmaceut. Clin. Res.

Khatib, A., M.Y. Kim and S.K. Chung, 2005. Antiinflammatory activities of Cinanamomum burmanni B1. Food Sci. Biotechnol., 14: 223-227.

Manaf, A., R.R. Tjandrawinata and D. Malinda, 2016. Insulin sensitizer in prediabetes: A clinical study with DLBS3233, a combined bioactive fraction of Cinnamomum burmanii and Lagerstroemia speciosa. Drug Design, Develop. Therapy, 10: 1279-1289. PMID: 27099473

Nailufar, F. and R.R. Tjandrawinata, 2011. Effect of DLBS3233, an insulin sensitizer, on fructose-induced insulin resistance rat. MEDICINUS, 24: 13-17.

Odeh, M. and A. Oliven, 2001. Hepatotoxicity related to sucralfate. Hepatol. Res., 20: 255-258. PMID: 11348860

Okabe, S., J.L. Roth and C.J. Pfeiffer, 1971. A method for experimental, penetrating gastric and duodenal ulcers in rats: Observations on normal healing. Am. J. Dig. Dis., 16: 277-284. DOI: $10.1007 / \mathrm{BF} 02235252$

Papich, M.G., 2016. Saunders Handbook of Veterinary Drugs: Small and Large Animal. 1st Edn., Elsevier Health Sciences, ISBN-10: 0323244858, pp: 928.

Silva, L.M., A. Allemand, D.A.G.B. Mendes, A.C. Santos and E. Andre et al., 2013. Ethanolic extract of roots from Arctium lappa L. accelerates the healing of acetic acid-induced gastric ulcer in rats: Involvement of the antioxidant system. Food Chem. Toxicol., 51: 179-187.

DOI: $10.1016 /$ j.fct.2012.09.026
Sitepu, R., D.S. Retnoningrum and R.R. Tjandrawinata, 2016. Molecular analysis of gene expression related to the effects of DLBS3233 treatment in differentiation of 3T3-L1 pre-adipocyte. Int. J. Pharmacy Pharmaceut. Sci.

Tandrasasmita, O.M., D.D. Wulan, F. Nailufar, J. Sinambela and R.R. Tjandrawinata, 2011. Glucoselowering effect of DLBS3233 is mediated through phosphorylation of tyrosine and upregulation of PPAR $\gamma$ and GLUT4 expression. Int. J. General Med., 4: 345-357. DOI: 10.2147/IJGM.S16517

Tandrasasmita, O.M., D.D. Wulan, F. Nailufar, J. Sinambela and R.R. Tjandrawinata, 2014. Glucoselowering effect of DLBS3233 is mediated through phosphorylation of tyrosine and upregulation of PPAR $\gamma$ and GLUT4 expression. Int. J. Gen. Med., 4: 345-57. PMID: 21674027

Tjandrawinata, R.R., F. Nailufar and P.F. Arifin, 2013. Hydrogen potassium adenosine triphosphatase activity inhibition and downregulation of its expression by bioactive fraction DLBS2411 from Cinnamomum burmannii in gastric parietal cells. Int. J. Gen. Med., 6: 807-815. PMID: 24101879

Tjandrawinata, R.R., D. Nofiarny, L.W. Susanto, P. Hendri and A. Clarissa, 2011. Symptomatic treatment of premenstrual syndrome and/or primary dysmenorrhea with DLBS1442, a bioactive extract of Phaleria macrocarpa. Int. J. Gen. Med., 4: 465-476. PMID: 21760747

$\mathrm{Wu}$, T.S. and T.T. Chou, 2011. Chinese medicinal compositions containing Bletilla and Cinnamomum and others used as anti-inflammatory and analgesic agents.

Wulandari, A.S., O.M. Tandrasasmita and R.R. Tjandrawinata, 2016. Bioactive Fraction DLBS211 from Cinnamomum burmannii, (Nees and T. Nees) blume as colon and gastroprotector by stimulating MUC5AC and cyclooxygenase-2 gene expression. IJPPS, 8: 202-207.

Yanagihara, G.R., A.G. Paiva, M.P. Neto, L.H. Torres and A.C. Shimano et al., 2015. Effects of long-term administration of omeprazole on bone mineral density and the mechanical properties of the bone. Rev. Bras. Ortop., 50: 232-238. PMID: 26229922 